\title{
Measuring Students' Perception of Classroom Quality in Private Universities in Ogun State, Nigeria Using SERVPERF
}

\author{
Oluwunmi Adedamola $0^{1}$ \\ Omirin Modupe $\mathbf{M}^{2}$
}

\author{
Ajayi Ayodele $\mathrm{C}^{3}$ \\ ${ }^{1}$ Department of Estate Management, Covenant University, Ota, Ogun State \\ ${ }^{2}$ Department of Estate Management, University of Lagos, Akoka, Lagos State \\ ${ }^{3}$ Department of Estate Management, Obafemi Awolowo University, Ile Ife, Osun State \\ Email funke.oluwunmi@covenantuniversity.edu.ng
}

Doi:10.5901/mjss.2016.v7n2p318

\begin{abstract}
In Nigeria, competition among private universities is becoming increasingly intense as investment in the sector is proving more and more viable. Students' satisfaction survey has been identified as an essential instrument for education providers to improve or enhance their service delivery in a bid to remain competitive. To demonstrate its use, this paper reports a research that uses a modified SERVPERF instrument to measure students' satisfaction with the classrooms - one of the essential academic facilities - in six out of eight private universities in Ogun State, Nigeria. A total of 1,141 questionnaires were administered to students and the data were analysed using SERVPERF dimensions (tangibility, responsiveness, reliability. assurance and empathy). Findings showed that students' satisfaction with service quality across the six private Universities is moderate. However, when the results are disaggregated to reflect the findings for each University, Babcock University is shown to have services that meet students' expectation most while Crawford University services meet their expectations least. This study is expected to pave the way for researchers who are interested in conducting further studies on students' satisfaction with service quality using SERVPERF in higher institutions in Nigeria and other countries of the world.
\end{abstract}

Keywords: Students' Satisfaction, Classroom, Private Universities, SERVPERF, Nigeria

\section{Introduction}

Feedback is very useful for service providers to map out plans for continuous improvement. It is vital to consistently measure the performance of educational facilities' service quality from students' perspective because they are directly involved in the education process. Apart from students being products of the educational institutions, they are the consumers of facilities services. Students' views on all aspects of their higher education experiences are therefore essential for monitoring the quality of services as well as the quality of education. The data gained will help the service provider and the stakeholders to make judgements about the level of the quality in those particular Universities (Hill, Lomas and MacGregor, 2003; Jusoh, Omain, Majid, Md Som and Shamsuddin, 2004). Most studies in educational institutions in Nigeria adopted the service quality (SERVQUAL) tool to measure service quality particularly from students' perspective (Mohammad, Gambo and Omirin, 2012; Omopupa and Abdulraheem, 2013). It is high time to know the current status and level of service quality in education using service performance (SERVPERF), which, according to Zeithaml (one of the founders of the SERVQUAL scale) is a better measuring instrument. It is against this background that this study is set to measure students' satisfaction with classroom facilities using SERVPERF scale in private Universities in Ogun State, Nigeria.

\section{Literature Review}

Monitoring of service quality has become a strategic option for many institutions of higher learning worldwide. The role of service quality has also become critical to the success of organizations, educational institutions inclusive (Landrum, Prybutok and Zhange, 2007). Perception of service quality is of paramount importance to due to its influence on the postenrolment communication behaviour of the students (Marilyn, 2005). Highly satisfied students are likely to spread positive 
words about their respective institutions, thus attracting new applicants with lower marketing costs. Private and public institutions of higher learning in developed and developing countries strive to provide quality services to their students in order to develop and maintain their reputation. In order to gain competitive advantage, higher institutions worldwide are fast adopting the quality management system philosophy (Sohail, Rajadurai and Rahman, 2003; Ramaiyah, Md.Zain and Ahmad, 2007). Most of the studies conducted in Nigeria and other parts of the world to measure service quality in higher education adopted SERVQUAL tools (Mohammad, Gambo and Omirin, 2012; Omopupa and Abdulraheem, 2013; Manjunatha and Shivalingaiah, 2004; Filiz, 2007; Hassanzadeh, Sharifabadi and Derakhshan, 2010; Khan, Ahmed and Nawaz, 2011; Khodayari and Khodayari, 2011; Ong and Nankervis, 2012).

However, another group of studies adopted the SERVPERF tools to measure service quality in educational institutions (Oldfield and Baron, 2000; Bigne, Moliner and Sanchez, 2003; Johari and Zainab, 2007; Brochado, 2009; Rodrigues, Barkur, Varambally and Motlagh, 2011). These studies measure service quality of facilities such as libraries, sport complexes, health centers amongst others and most of these studies were conducted in Spain, US, Malaysia and Turkey. One crucial area where few research works have been conducted using either SERVQUAL or SERVPERF tool is the classroom, which is one of the essential academic facilities in institutions of higher learning. Classrooms are part of the curricular structure that link different disciplines around a common theme. Despite the importance attached to this facility, research has shown that students are not satisfied with their classrooms (Coffman and Gilligan, 2000). Hence, there is a need for continuous assessment of this crucial facility.

As a result, several studies have been conducted to ensure quality classrooms that satisfy students. The study of Kleen and Shell (2001) used a variation of the SERVQUAL tool to measure students' satisfaction with instructional technology tools used in their classrooms in the USA. Findings show that student satisfaction varied by course discipline, instructional technology, anticipated grade, and frequency of use. Female respondents were less satisfied than male respondents. Satisfaction generally rose with frequency of use. There are significant variations of satisfaction by discipline and technology choice, but little interaction effect. Factor analysis did not reveal the five hypothesized dimensions of SERVQUAL.

Also in the US, Stodnick and Rogers (2007) used the SERVQUAL scale to measure the quality of the classroom experience. The findings show that the SERVQUAL scale exhibits both reliability and convergent as well as divergent validity; in fact, it out-performs traditional student assessment scales. Moreover, the scale can explain significant degrees of variance in student-related outcome variables such as satisfaction and learning. This innovative approach to measuring classroom service quality does indeed show that students can be viewed as customers and has far-reaching implications to all stakeholders in the delivery of higher education services.

Another study in the US by Kleen, Shell and Zachry (2011) used a SERVQUAL-inspired instrument to measure students' satisfaction with technology tools used in Accounting Information System (AIS) classrooms. Faculties from six schools administered the instrument to 151 students in AIS classes. Findings showed that in-class computer activities generated the highest satisfaction among students, live software demonstrations the least; and satisfaction varied little by gender or age group. Student in-class computer activities showed the most reaction of satisfaction to usage rates, and in all cases greater usage led to higher satisfaction. In some instances, the satisfaction score for a question differed across technology groups, but these differences are cannot be generalised.

Foropon, Seiple and Kerbache (2013) examined service quality provided in the classroom, by applying the SERVQUAL instrument in two operations management (OM) courses located at the two extremes of the higher education spectrum in the US and France. The first SERVQUAL gap analysis assessed an OM undergraduate course (at the low end of the spectrum), whereas the second SERVQUAL gap analysis appraised an OM executive education course (at the highest end of the spectrum). Findings indicated that the use of SERVQUAL results could lead to improving the performance of service quality dimensions in the classroom at the undergraduate level, and expectations of undergraduate students and executive education participants could be exceeded on multiple service quality dimensions such as reliability, responsiveness and tangibles.

In line with this review, it is obvious that several studies have been carried out to measure the quality of classrooms in educational institutions using the SERVQUAL tool. However, in Nigeria, particularly in private Universities in Ogun State, the service quality of classrooms has neither been measured using the SERVQUAL nor the SERVPERF tool. Hence, this study is set to bridge this gap by applying the SERVPERF tool to measure the quality of classrooms in six private Universities in Ogun State, Nigeria.

\section{Research Methods}

This study employed the statistical formula by Asika (2004) to determine a suitable sample size for students in each 
selected private University. The formula is as follows:

$\mathrm{n}=\mathrm{N} / \mathrm{1}+\mathrm{N}(\mathrm{b})^{2}$

Where:

$\mathrm{n}=$ required sample size

$N=$ Population Size

$b=$ Maximum acceptable error margin (10\%)

In all, a total of 1,141 modified SERVPERF questionnaires were randomly administered to the students. The original SERVPERF scale contains 22 statements, however, the modified SERVPERF used for this study contains 28 statements [see Appendix A categorised under Tangibility (statements 1-15); Responsiveness (statements 16-19); Reliability (statements 20-22); Assurance (statements 23-25) and Empathy (statements 26-28)]. Students' views were measured in a graded manner, using a 5-point Likert scale. Data was analysed using descriptive statistical techniques. The decision rule for the interpretation of the data is in line with Ahmed (2013) interpretation of ranking of Likert scale of 5 to 1 as follows:

1. Positive statement: 4 to 5 scores represent positive feelings about the attribute being described by the attitudinal question,

2. Negative statement: 1 to 2 scores represent negative feelings about the attribute being described by the attitudinal question,

3. Neutral statement: 3 scores represent nuetral feelings about the attribute being described by the attitudinal question.

\section{Results and Discussion}

$72 \%$ of the modified SERVPERF questionnaires distributed were found useful (Table 1). Out of these, $47 \%$ were male and $53 \%$ were female; the majority were Science and Technology students, single and sponsored by their parents (Table 2). They were between 16 and 20 years, in 200 and 300-level of their course programmes.

Table 1: Response Rate

\begin{tabular}{|c|l|c|c|c|}
\hline \multirow{2}{*}{ S/N } & \multirow{2}{*}{ University } & \multicolumn{2}{|c|}{ No. of Questionnaires } & \multirow{2}{*}{ Percentage (\%) } \\
\cline { 3 - 4 } & Administered & Retrieved & \\
\hline 1 & Babcock University (BU) & 198 & 136 & 69 \\
\hline 2 & Covenant University (CU) & 199 & 162 & 81 \\
\hline 3 & Redeemers' University (RUN) & 187 & 140 & 75 \\
\hline 4 & Bells University (Bells) & 187 & 116 & 62 \\
\hline 5 & Crescent University (CRE) & 186 & 108 & 58 \\
\hline 6 & Crawford University (CRA) & 184 & 154 & 84 \\
\hline & Total & $\mathbf{1 , 1 4 1}$ & $\mathbf{8 1 6}$ & $\mathbf{7 2}$ \\
\hline
\end{tabular}

Table 2: Comparison of Students' Characteristics across the Six Private Universities

\begin{tabular}{|c|c|c|c|c|c|c|c|c|c|}
\hline \multirow[t]{2}{*}{$S / N$} & \multirow[t]{2}{*}{ Characteristics /Statistics } & \multirow[t]{2}{*}{ Sub-headings } & BU & CU & RUN & Bells & CRE & CRA & \\
\hline & & & $F(\%)$ & $F(\%)$ & $F(\%)$ & $\mathrm{F}(\%)$ & $F(\%)$ & $F(\%)$ & \\
\hline \multirow[t]{3}{*}{1} & Academic Proc & Science \& Technology & $44(32)$ & $81(50)$ & $37(26)$ & $86(74)$ & $62(57)$ & $118(77)$ & 0 \\
\hline & Classifi & & $44(32)$ & $32(20)$ & $85(61)$ & $30(26)$ & $28(26)$ & $36(23)$ & 0 \\
\hline & & & $48(36)$ & $49(30)$ & $18(13)$ & $\mathrm{N} / \mathrm{A}$ & 18 (17) & N/A & 1 \\
\hline \multirow[t]{2}{*}{2} & Sex & Male & $61(45)$ & $90(56)$ & $50(36)$ & $60(52)$ & $56(52)$ & $59(38)$ & \\
\hline & & Female & 75 (55) & $72(44)$ & $90(64)$ & 56 (48) & 52 (48) & $92(62)$ & 53 \\
\hline \multirow[t]{5}{*}{3} & Age & $<16$ yrs & 15 (11) & $0(0)$ & $1(1$ & $0(0)$ & $10(9)$ & $6(4)$ & \\
\hline & & $16-20 \mathrm{yrs}$ & $85(63)$ & $39(24)$ & $115(82)$ & $53(46)$ & 49 (45) & $112(73)$ & 55 \\
\hline & & $21-25$ yrs & $29(21)$ & $123(76)$ & $24(17)$ & $59(51)$ & $41(38)$ & 30 (19) & 0 \\
\hline & & $26-30 \mathrm{yrs}$ & $7(5)$ & $0(0)$ & $0(0)$ & $4(3)$ & $6(6)$ & $6(4)$ & 3 \\
\hline & & $>30 \mathrm{yrs}$ & $0(0)$ & $0(0)$ & $0(0)$ & $0(0)$ & $2(2)$ & $0(0)$ & \\
\hline \multirow[t]{2}{*}{4} & Year of Study & 100-Level & $21(15)$ & $0(0)$ & $68(48)$ & $9(8)$ & $11(10)$ & $0(0)$ & 1 \\
\hline & & 200-Level & $43(32)$ & $6(4)$ & $29(21)$ & 14 (12) & $51(47)$ & 74 (48) & \\
\hline
\end{tabular}




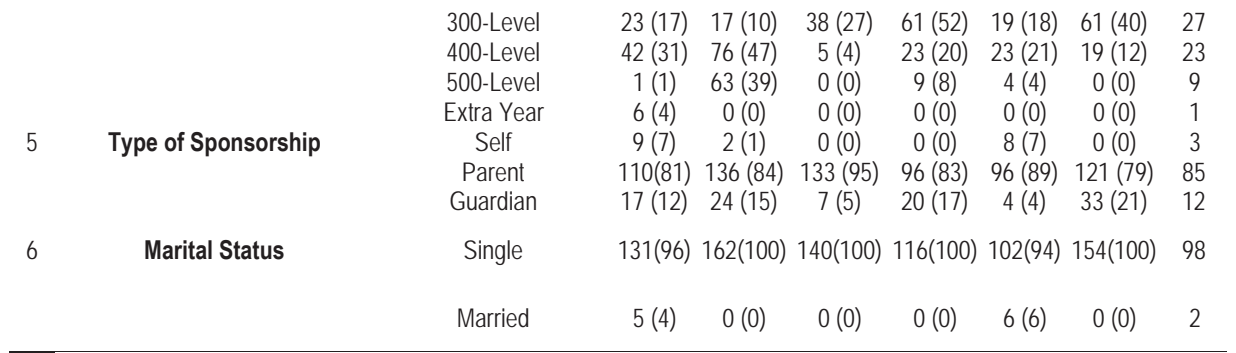

The analysis in Table 3 reveals that the average service quality dimension of the respondents on tangibility, responsiveness, reliability, assurance and empathy are $3.31,3.63,3.58,3.75$ and 3.83 respectively. This shows that tangibles, which represent the physical appearance of the facilities of an educational institution, are not a matter of concern to students. Generally, the findings suggest that; students rate their institution's services more on the grounds of quality of education (reliability, responsiveness, assurance and empathy) not on the basis of the physical appearance of the facilities. The overall average service quality dimension of 3.62 indicates that the quality of classroom services overall is above average.

Table 3: Students' Perception of Classrooms Services: Comparison of Mean Scores across Six Private Universities

\begin{tabular}{|c|c|c|c|c|c|c|c|c|}
\hline \multirow{2}{*}{ Service Quality Dimensions } & & $\mathrm{BU}$ & CU & RUN & Bells & CRE & CRA & \multirow{2}{*}{ Average Mean } \\
\hline & Services & Mean & Mean & Mean & Mean & Mean & Mean & \\
\hline \multirow{15}{*}{ Tangibility } & S1 & 4.21 & 2.94 & 4.10 & 2.06 & \begin{tabular}{|l|}
3.62 \\
\end{tabular} & 3.14 & 3.34 \\
\hline & S2 & 4.40 & 4.04 & 4.18 & 3.22 & 3.63 & 3.27 & 3.79 \\
\hline & S3 & 4.13 & 2.96 & 3.98 & 1.96 & 3.45 & 3.08 & 3.26 \\
\hline & S4 & 4.68 & 3.00 & 3.93 & 3.70 & 3.21 & 3.16 & 3.61 \\
\hline & S5 & 4.40 & 3.79 & 4.11 & 3.91 & 3.44 & 3.20 & 3.81 \\
\hline & S6 & 4.65 & 4.32 & 4.25 & 3.58 & 3.21 & 2.88 & 3.81 \\
\hline & S7 & 4.57 & 4.31 & 4.25 & 3.90 & 3.21 & 3.16 & 3.90 \\
\hline & S8 & 2.74 & 3.12 & 3.95 & 3.68 & 3.35 & 3.03 & 3.31 \\
\hline & S9 & 4.28 & 4.51 & 4.00 & 3.80 & 3.38 & 3.17 & 3.85 \\
\hline & S10 & 4.06 & \begin{tabular}{|l|}
4.49 \\
\end{tabular} & 4.17 & 1.95 & 3.52 & 2.99 & 3.53 \\
\hline & S11 & 4.58 & \begin{tabular}{|l|}
4.12 \\
\end{tabular} & 4.01 & 3.57 & 3.06 & 3.19 & 3.75 \\
\hline & S12 & 4.47 & 3.49 & 3.98 & 3.84 & 3.15 & 2.95 & 3.65 \\
\hline & S13 & 2.49 & 2.93 & 2.01 & 1.96 & \begin{tabular}{|l|}
3.01 \\
\end{tabular} & 2.88 & 2.54 \\
\hline & S14 & 4.49 & 3.55 & 3.79 & 3.66 & 3.53 & 3.08 & 3.68 \\
\hline & S15 & 4.06 & 3.46 & 3.88 & 3.75 & \begin{tabular}{|l|}
3.44 \\
\end{tabular} & 3.02 & 3.60 \\
\hline \multicolumn{2}{|l|}{ Average Tangibility } & 4.15 & 3.67 & 3.91 & 3.24 & 3.35 & 3.08 & 3.31 \\
\hline \multirow{4}{*}{ Responsiveness } & S16 & 4.29 & 3.02 & 4.01 & 3.81 & 3.69 & 3.21 & 3.67 \\
\hline & S17 & 4.56 & 3.04 & 4.07 & 3.74 & 3.60 & 3.08 & 3.68 \\
\hline & S18 & 4.45 & 3.62 & 4.11 & 3.66 & 3.24 & \begin{tabular}{|l|l|}
3.27 \\
\end{tabular} & 3.73 \\
\hline & S19 & 4.33 & 3.05 & 4.14 & 3.22 & 2.70 & 3.28 & 3.45 \\
\hline \multicolumn{2}{|l|}{ Average Responsiveness } & 4.41 & 3.18 & 4.08 & 3.61 & 3.31 & 3.21 & 3.63 \\
\hline \multirow{3}{*}{ Reliability } & S20 & 4.60 & 3.61 & 3.98 & 3.73 & 3.96 & 3.58 & 3.41 \\
\hline & S21 & 4.51 & 2.98 & 4.00 & 3.55 & 3.32 & 3.53 & 3.65 \\
\hline & S22 & 4.57 & 2.94 & 4.23 & 3.84 & 3.42 & 3.15 & 3.69 \\
\hline \multicolumn{2}{|l|}{ Average Reliability } & 4.56 & 3.18 & 4.07 & 3.71 & 3.57 & 3.42 & 3.58 \\
\hline \multirow{3}{*}{ Assurance } & S23 & 4.13 & 3.60 & 4.16 & 3.73 & 3.56 & 3.47 & 3.77 \\
\hline & S24 & 4.51 & 2.98 & 4.26 & 3.64 & 3.88 & 3.49 & 3.79 \\
\hline & S25 & 4.60 & 2.98 & 4.24 & 3.58 & 3.69 & 3.03 & 3.68 \\
\hline \multicolumn{2}{|l|}{ Average Assurance } & 4.41 & 3.19 & 4.22 & 3.65 & 3.71 & 3.33 & 3.75 \\
\hline \multirow{3}{*}{ Empathy } & S26 & 4.54 & 3.02 & 4.19 & 3.79 & 3.26 & 3.58 & 3.73 \\
\hline & S27 & 4.63 & 3.62 & 4.27 & 3.59 & 3.45 & 3.53 & 3.85 \\
\hline & S28 & 4.37 & 4.09 & 4.53 & 3.78 & 3.18 & 3.50 & 3.91 \\
\hline \multicolumn{2}{|l|}{ Average Empathy } & 4.51 & 3.58 & 4.33 & 3.72 & 3.30 & 3.54 & 3.83 \\
\hline
\end{tabular}


However, when the results are disaggregated to reflect the findings for each University, Babcock University is shown to have services that meet students' expectation most with mean scores of 4.15, 4.41, 4.56, 4.41, 4.51 for tangibility, responsiveness, reliability, assurance and empathy respectively. Following this is Redeemers University which has mean scores of 3.91, 4.08, 4.07, 4.22 and 4.33 in tangibility, responsiveness, reliability, assurance and empathy respectively. Next to this are Bells University, Crescent University, Covenant University and Crawford University in that order, However, Covenant University has a higher mean score of 3.67 in tangibility (physical appearance of the classroom facilities) when compared to Bells $(3,24)$, Crescent $(3.35)$ and Crawford (3.08) Universities. These findings might have implications on students' patronage of the Universities.

\section{Recommendation and Concluding Remarks}

This study has shown that service quality across the six private Universities (Babcock, Covenant, Redeemers, The Bells, Crescent and Crawford Universities) was moderate from students' perspective. This means that there is room for improvement across board. Hence, the service providers must put more effort and commitment into the areas of tangibility (particularly in Bells, Crescent and Crawford Universities); responsiveness (in Covenant, Crescent and Crawford Universities); reliability (in Covenant and Crawford Universities); assurance (in Covenant and Crawford Universities) and empathy (in Crescent University). This is because it is important that students are satisfied in order to get the best from them. According to Ahmed, Nawaz, Zulfqar, Zafar, Shaukat, Usman, Rehman and Ahmed (2010), the higher their level of satisfaction, the greater will be the quality of students produced.

\section{References}

Ahmed, L. (2013). Assessment of Residential Mortgage Recovery Strategies in the Nigerian Lending Market, (Unpublished PGD Thesis), Department of Estate Management, Federal University of Technology, Akure, Ondo State, Nigeria.

Ahmed, I., Nawaz, M. M., Zulfqar, A., Zafar, A., Shaukat, M. Z., Usman, A., Rehman, W., \& Ahmed, N. (2010). Does Service Quality Affect Students' Performance? Evidence from Institute of Higher Learning. African Journal of Business Management, 4(12), 2527-2533.

Asika, N. (2004). Research Methodology: A Process Approach (1st Ed.) Lagos: Longman Nigeria Plc.

Bigne, E., Moliner, M. A. \& Sanchez, J. (2003). Perceived Quality and Satisfaction in Multi-service Organizations: The Case of Spanish Public Services. The Journal of Services Marketing, 17(4), 420-442.

Brochado, A. (2009). Comparing Alternative Instruments to Measure Service Quality in Higher Education. Quality Assurance in Education, 17 (2), $174-190$.

Coffman, D. L. \& Gilligan, T. D. (2000). The Relationship of Social Support, Self-efficacy and Stress with Life Satisfaction among First Year College Students. Poster presented at the $70^{\text {th }}$ Annual Meeting of the Eastern Psychological Association, Baltimore, MD.

Filiz, Z. (2007). Service Quality of University Library: A Survey amongst Students at Osmangazi University and Anadolu University. Ekonometri Ve Istatistik Sayi, 5, 1-19.

Foropon, C., Seiple, R., \& Kerbache, L. (2013) Using Servqual to Examine Service Quality in the Classroom: Analyses of Undergraduate and Executive Education Operations Management Courses. International Journal of Business \& Management, 8(20), 1-13. Available@http//www.umanitoba.ca

Hassanzadeh, M., Sharifabadi, S. R., \& Derakhshan, M. (2010). Assessment of Service Quality at Central Library of Management and Planning Organization (MPO), Iran. International Journal of Information Science and Management. 8 (1), 107-118.

Hill, Y., Lomas, L., \& MacGregor, J. (2003). Students' Perceptions of Quality in Higher Education. Quality Assurance in Education, 11(1), $15-20$.

Johari, R. \& Zainab, A. N. (2007). Identifying What Services Need To Be Improved by Measuring the Library's Performance. Malaysian Journal of Library and Information Science, 12(1), 35-53.

Jusoh, A., Omain, S. Z., Majid, N. A., Md Som, H., \& Shamsuddin, A. S. (2004). Service Quality in Higher Education: Management Students' Perspective. A Research Submitted to Management Department, Faculty of Management and Human Resource Development, University of Technology, Malaysia. Available@http://eprints.utm.my/3763/1/AHMADJUSOH71982.pdf

Khan, M. M., Ahmed, I., \& Nawaz, M. M. (2011). Student's Perspective of Service Quality in Higher Learning Institutions: An Evidence Based Approach. International Journal of Business and Social Science. 2(11), 159-164.

Khodayari, F. \& Khodayari, B. (2011). Service Quality in Higher Education, Case Study: Measuring Service Quality of Islamic Azad University; Firoozkooh Branch. Interdisciplinary Journal of Research in Business. 1(9), 38-46.

Kleen, B. A. \& Shell, L. W. (2001). SERVQUAL-Based Measurement of Student Satisfaction with Classroom Instructional Technologies: A 2001 Update. Presented at International Academy for Information Management (IAIM) Annual Conference: International Conference on Informatics Education and Research (ICIER), December 14-16, New Orleans, LA.

Kleen, B. A., Shell, L. W. \& Zachry, B. R. (2011) Students Respond to the Use of Instructional Technology in the Accounting Information Systems Classroom. The Review of Business Information Systems, 6(1), 51-60. Available@http://www.cluteinstitute.com/ojs/ index.php/RBIS/article/view/4577 
Landrum H., Prybutok V. K., \& Zhange X. (2007). A Comparison of Magal's Service Quality Instruments with SERVPERF. Information Management, 44, 104-113.

Manjunatha, K. \& Shivalingaiah, D. (2004). Customer's Perception of Service Quality in Libraries. Annals of Library and Information Studies, 51(4), 145-151.

Marilyn, R. (2005). Marketing Education: A Review of Service Quality Perceptions among International Students. International Journal of Contemporary Hospitality Management, 17(1), 65 - 77

Mohammad, M. I., Gambo, Y. L., \& Omirin, M. M. (2012). Assessing Facilities Management Service in Postgraduate Hostel Using Servqual Technique. Journal of Emerging Trends in Economics and Management Sciences (JETEMS), 3(3), 252-256.

Oldfield, B. M. \& Baron, S. (2000). Student Perceptions of Service Quality in a UK University Business and Management Faculty. Quality Assurance in Education, 8 (2), 85-95.

Omopupa, K. T. \& Abdulraheem, I. (2013) The Quality of Nigerian Higher Education and the Funding of Library Resources. Ozean Journal of Social Science, 6(2), $43-53$.

Ong, W. M. \& Nankervis, A. (2012). Service Quality in Higher Education: Students'_Perceptions in Australia and Malaysia. Review of Integrative Business and Economic Research, 1 (1): 277 - 290.

Ramaiyah, A., Md. Zain, A.N., \& Ahmad, H. (2007). Exploring the Dimensions of Service Quality in Higher Education Research. In: Regional Conference on Quality in Higher Education "Quality Driven Initiatives: Sharing Good Practices in Higher Education" (Unpublished).

Rodrigues, L. L. R., Barkur, G., Varambally, K. V. M., \& Motlagh, F. G. (2011). Comparison of SERVQUAL and SERVPERF Metrics: An Empirical Study. The TQM Journal, 23(6), $629-643$.

Sohail, M. S. \& Shaikh, N. M. (2004). Quest for Excellent in Business Education: A Study of Student Impressions of Service Quality. The International Journal of Educational Management, 18(1), 58-65.

Stodnick, M. \& Rogers, P. (2007). Using SERVQUAL to Measure the Quality of the Classroom Experience. Decision Sciences, Journal of Innovative Education, 6(1), 115 - 133. Available@http://onlinelibrary.wiley.com/doi/10.1111/j.1540-4609.2007.00162.x/abstract

\section{Appendix A: Modified SERVPERF Statements for Classrooms Services}

\begin{tabular}{|c|c|c|c|}
\hline $\mathrm{S} / \mathrm{N}$ & Dimension of Service Quality Attribute & $\mathrm{S} / \mathrm{N}$ & Dimension of Service Quality Attribute \\
\hline 1 & The classrooms are modern and up-to-date & 15 & There is adequate space per student \\
\hline 2 & The physical environment of the classrooms are quiet enough to aid learning & 16 & $\begin{array}{l}\text { Lecturers always welcome students' questions and } \\
\text { comments }\end{array}$ \\
\hline 3 & $\begin{array}{l}\text { The classrooms are equipped with all the necessary equipment to aid } \\
\text { learning (e.g. projector, whiteboard, internet e.t.c) }\end{array}$ & 17 & Lecturers provide the students with the expected knowledge \\
\hline 4 & The classrooms are clean and free of distractions & 18 & Lecturers understand the individual needs of their students \\
\hline 5 & The classrooms are well ventilated and comfortable & 19 & $\begin{array}{l}\text { The lecturer is willing to go out of his or her way to help } \\
\text { students }\end{array}$ \\
\hline 6 & The lighting quality of classrooms are functional & 20 & $\begin{array}{l}\text { Lecturers are confident in their expert understanding of a } \\
\text { course }\end{array}$ \\
\hline 7 & There is sufficient natural and artificial lighting in the classrooms & 21 & The lecturers are dependable \\
\hline 8 & There is sufficient parking space around the classrooms & 22 & The lecturer reliably correct information when needed \\
\hline 9 & There is adequate furniture (e.g. chairs, tables) & 23 & Lecturers are fair and impartial in grading \\
\hline 10 & There is sufficient number of toilets & 24 & Lecturers have vast knowledge in their field \\
\hline 11 & There is separate toilet for male and female & 25 & $\begin{array}{l}\text { Lecturer are always willing to answer students' questions } \\
\text { thoroughly }\end{array}$ \\
\hline 12 & There is sufficient water supply in the toilets & 26 & Lecturers care for students \\
\hline 13 & There is adequate escape routes & 27 & Lecturers are genuinely concerned about students \\
\hline 14 & There is adequate electricity supply & 28 & Lecturers encourage and motivate students to do their best \\
\hline
\end{tabular}

